\title{
Religião e protoglobalização. A globalizaÇÃo CONTEMPORÂNEA COMO DECALQUE LAICO DA UNIVERSALIZAÇÃO RELIGIOSA MODERNA
}

\author{
José Eduardo Franco
}

\begin{abstract}
Resumo
Este estudo exploratório pretende analisar como determinados axiomas teológicos bíblicos forneceram fundamentos para o ideário universalista do cristianismo como primeira religiosa com um horizonte expansionista à escala global. À luz desta perspetiva teórica situada no perímetro epistemológico da história religiosa, do imaginário e das mentalidades, podemos problematizar o fenómeno da protoglobalização que emerge na Época Moderna como tendo, na sua raiz, um móbil religioso, como religiosas são a sua legitimação e explicação. E foi ainda do meio religioso que surgiram os primeiros instrumentos e soluções globais para atender aos desafios trazidos pelo processo de conhecimento do mundo, em que os povos abriam as portas para serem conhecidos e receberem, em paz ou em guerra, as interinfluências dessa abertura. Esquecemos, em grande medida, o tempo seminal do atribulado início desta globalização que hoje vivenciamos de forma plena, mas não menos atribuladamente. Alguns desses instrumentos criados, com motivação religiosa nos séculos XVI e XVII, para responder ao mundo aberto são hoje reproduzidos, esvaziados desse referente, de modos e por meios variados, de que as multinacionais são a melhor expressão. Mas o processo moderno de secularização acabou por cortar o fio de ligação com o religioso, assumindo um cunho laico e civil.
\end{abstract}

\section{Palavras-Chave}

Globalização; religião; Cristianismo; educação; missionação; multinacionais

\begin{abstract}
This exploratory study aims to analyse how certain biblical theological axioms provided the foundations for the universalist ideas of Christianity as the first religion with a globally expansionist outlook. Based on this theoretical perspective situated within the epistemological boundaries of religious history, the imagination and mentalities, we can examine the phenomenon of protoglobalization that emerges in the modern age as having a religious motive at its heart, just as its legitimation and explanation are also religious. It was also from the religious sphere that the first global instruments and solutions emerged to deal with the challenges brought by the process of becoming acquainted with the world, where peoples opened their doors to being known and received, peacefully or otherwise, the inter-influences of that openness. We largely forget the seminal times of the turbulent beginnings of the globalization that today we experience fully but no less turbulently. Some of the instruments created with a religious motivation in the $16^{\text {th }}$ and $17^{\text {th }}$ centuries to respond to the open world are today reproduced, stripped of that point of reference, in different ways and by different means, of which multinationals are the best example. But the modern secularization process ended up cutting the connection with the religious, taking on an areligious, civil nature.
\end{abstract}

\section{Palavras-chave}

Globalization; religion; christianity; education; missionarismo; multinationals 
Vivemos o início de um começo.

Edgar Morin

O mito é um arranjo do passado, seja ele real ou imaginado, em padrões que reforçam os valores e as aspirações mais profundas de uma cultura. (...) Os mitos estão tão carregados de sentido que vivemos e morremos por eles. São os mapas que as culturas usam para navegar no tempo. Ronald Wright

A história global nasceu da convicção de que os meios que os historiadores estavam usando para analisar o passado deixaram de ser suficientes. A globalização lançou um desafio fundamental às ciências sociais e aos relatos dominantes sobre a mudança social.

Sebastian Conrad

\section{HistoriogÉNESE bÍbLICA E A IDEIA TEOLÓGICA DE UMA GLOBALIZAÇÃo PRIMORDIAL}

As religiões criacionistas, nomeadamente as de tradição abraâmica (judaísmo, cristianismo e islamismo), estabeleceram uma visão do mundo em que Deus é o senhorio e o ser humano por Ele criado uma espécie de inquilino qualificado. Recorrendo a uma analogia retirada do campo semântico agrícola, o homem criado à imagem de Deus (imago Dei) é uma espécie de "benfeitor", "feitor" ou colono de uma Terra que lhe foi confiada para explorar, (re)conhecer, nomear (classificar) e cuidar (Kung, 2007, p. 19).

A ideia de posse delegada da Terra é uma das características mais complexas da relação do Homem com a natureza, com implicações na perceção do papel ecológico do ser humano, como também no seu conhecimento e reconhecimento do mundo. As protologias judaico-cristãs e islâmica determinam que Deus criou global e completamente toda a realidade: o mundo e o cosmos. Ao ser humano é dada a condição de ícone, imagem, ou seja, representante de Deus na Terra, e de ser o primeiro a realizar o seu conhecimento e reconhecimento, classificando tudo o que vê, que o mesmo é dizer, dando nome às coisas criadas em movimento progressivo (Gn 1$)^{1}$.

O pecado da primeira idade da história, em perspetiva bíblica, subverte este processo em curso. A queda do primeiro casal humano quebra a harmonia inicial e como que opera o desencantamento da criação e do paraíso primigénio. Começa então verdadeiramente a história humana, com o seu cortejo de sucessos e insucessos, de alegrias e tragédias, numa trajetória descendente até à degradação completa. Segue-se o castigo do dilúvio universal, mas também a preservação, in extremis, dos seres vivos da fúria dos fenómenos naturais através de uma arca.

\footnotetext{
' O poder de nomeação das coisas novas é uma prerrogativa divina que está teologicamente ligada ao ato genesíaco da criação, mas que foi dado ao Homem como competência delegada (Vaz, 2007). Assim, o Homem recebe uma espécie de delegação divina para nomear, para dar identidade às coisas dispostas sob a sua dominação. Esta prerrogativa delegada é típica das idades primordiais (Ricoeur, 1986).
} 


\title{
ESQUEMA HERMENÊUTICO TRIÁDICO DA HISTÓRIA: HARMONIA INICIAL/QUEDA/ REGENERAÇÃO
}

Esta narrativa paradigmática constitui, primeiro no quadro do percurso histórico de Israel, depois aplicada à história cristã e das nações que se modelam neste mesmo quadro, uma grelha de leitura das derivas do grande percurso da humanidade: quando as sociedades humanas atingem um estado de corrupção intolerável, Deus manda o redentor. João Medina, falando sobre este modelo de degradação/redenção, coloca em contraste as expectativas dos movimentos messiânicos e a lógica teológica de fundo da conceção doutrinal judaica do ritmo da história:

\begin{abstract}
o que é sobretudo verdade no tocante aos movimentos de ativismo messiânico em que se pretende "apressar a vinda" do Messias, não obstante a advertência que, no salmo 45, 3, dava o Midrash Tehillim: "Israel disse a Deus: quando nos virás resgatar? E Deus respondeu: quando tiveres caído no mais baixo, então te virei resgatar!" Ou, como se advertia no livro de Esdras (IV, 34): "Não sejas mais apressado que o teu Criador". (Medina, 1995, pp. 270-271)
\end{abstract}

Depois do primeiro castigo universal infligido à humanidade, operou-se também a primeira palingenesia. Então começou a segunda idade o mundo e a primeira aliança entre Deus e os homens, selada pelas esplendorosas cores do arco-íris. Por mandato divino, Noé, capitão da arca salvadora, e seus descendentes fizeram o repovoamento dos quatro cantos do mundo, recontando-se a história dos povos e das nações a partir de então e com base nessa visão global da refundação do mundo estabelecida pelo relato do Génesis. Assim sendo, a matriz genealógico-sociogénica da humanidade é miticamente estabelecida com esta definição da tábua das nações e o povoamento pós-diluviano da Terra. Neste caso, como noutros, explica L. Filipe Barreto (1996, p. 40) que, nestes livros bíblicos, "através do princípio da analogia, figuras como as de Adão, da Arca de Noé, do Dilúvio, do Apóstolo S. Tomé, das tribos perdidas de Israel, servem para caracterizar, localmente, uma cultura ou para integrar toda e qualquer unidade sociocultural no quadro universal do mundo".

\section{Proto-história humANA E CRISTÃ E A CONSTRUÇÃo Do MITO DAS ORIGENS DAS NAÇÕES}

À luz desta tábua global da génese das nações pós-diluvianas, as histórias mitificantes das nações europeias são recontadas por historiadores medievais e protomodernos - em Portugal, Fernando Oliveira e Bernardo de Brito, em Espanha, Floriano Ocampo e Estabán Garibay e Zamaloa -, na pretensão de conferirem aos seus reinos uma primigénia antiguidade bíblica. $E$ é também à luz dessa tábua mítica universal, uma espécie de código da historiogénese e da sociogénese das nações estabelecida no primeiro livro da Bíblia, que o mundo é percecionado como global, tendo a presença do Homem de ser também global, para garantir o seu domínio². Foi com base nesta matriz dos povos

${ }^{2}$ Claude-Gilbert Dubois (1972, p. 18), escrevendo sobre a problemática dos mitos das origens das nações europeias estabelecidos nos dealbar da Modernidade considera que "a génese do mito não pode ser dissociada do terreno histórico sobre 
que se passou, em viagens de descoberta, a fazer o reconhecimento dessa primigénia dispersão universal da humanidade e da origem das nações (cf. Franco, 2000).

Nas narrativas mitológicas bíblicas, estruturadas por um ideário etiológico que visa a explicação genesíaca abrangente das realidades tangíveis e intangíveis, emerge uma leitura religiosa do mundo consabido como global. A dispersão universal de gentes e de línguas nos tempos primordiais narrados pela Bíblia assenta num querer divino. Esta grelha hermenêutica judaico-cristã tem a sua linha fundante na visão teológica da história elaborada na patrística dos primeiros séculos do cristianismo, tendo como proto-obra a História Eclesiástica de Eusébio de Cesareia, considerado o pai da história eclesiástica, também cognominado o "Heródoto cristão". Tal como a sua Histórica Eclesiástica, também a sua Crónica tenta produzir uma narrativa universal à luz da nova mundividência e da historiovidência cristã (Eusébio de Cesareia, 2015), como mais tarde fará, de forma mais completa e filosoficamente mais profunda, o genial S. ${ }^{\text {to }}$ Agostinho. Com efeito, a teologia e a filosofia da história do bispo de Hipona, consignadas na sua monumental Cidade de Deus (Santo Agostinho, 1991-1995), estão na génese do pensamento historiográfico desenvolvido na Idade Média, para o qual Deus é indubitavelmente o dispensador das vitórias e dos fracassos dos homens, numa demonstração do poder divino sobre a história. Como explica ). Veríssimo Serrão (1969, p. 97):

para os autores que interpretam os sucessos como uma causa eficiente, Deus surge, através do seu poder sobrenatural, a conduzir os destinos humanos e a marcar o rumo da História. Nesta conceção, o homem surge como simples intérprete da vontade divina, como o ator de um pensamento que, segundo Leibniz, dirige o Mundo por meio de uma harmonia praestabilita.

Assim sendo, essa mitificada globalização primeva, que podemos designar como genesíaca, descrita no primeiro livro do Antigo Testamento, torna-se prefiguração de uma globalização religiosa no dealbar da nossa era, ou seja, no projeto de universalização do cristianismo, cujas sementes estavam espraiadas em profetas como o segundo Isaías. De facto, a ideia embrionária de uma religião universal corresponde a uma evolução ali patente e marcada de uma determinada noção de Deus; passa-se progressivamente de um Deus territorial para um Deus global, razão pela qual o seu culto e o acolhimento humano da sua mensagem também devem estar destinados a toda a humanidade (Wright, 2011).

Deparamos aqui com o tema fulcral das representações, que marca o progresso do conhecimento e da ideia de mundo criado. A noção de divindade e a fé exclusiva na centralidade monoteísta de um só Deus favoreceu o ideal de expansão e globalização religiosa que se tornou motor de outras globalizações; e as representações do mundo são igualmente significativas do movimento globalizador. Na modernidade, como lembra

o qual ele se apoia. Estas crenças assumem o aspeto de alegorias, cujo sentido é determinado pela conjuntura histórica; é uma maneira de exprimir reivindicações que pertencem a um tempo preciso e a aspirações em relação direta com a atualidade histórica". 
Ramada Curto (2016, p. 286), "os mapas-mundo são um dos casos mais evidentes de representações globais". Estes mapas globais expressam já o desejo e o resultado de um mundo em processo de conhecimento e reconhecimento; ao contrário do que acontecia até à modernidade, em que essas representações cartográficas tinham uma componente imaginária muito forte, para poderem cobrir o saber (ou a ignorância) sobre a parte do planeta que não se conhecia ou se conhecia por notícias pouco rigorosas e muitas vezes efabuladas.

\section{Profecia E Utopia de UMA ReLIGIÃo UNIVERSAL: MOTOR DA GLOBALIZAÇÃo}

Realmente, o cristianismo potencia a globalização de um Deus único, tornando-se a primeira religião com vocação radicalmente universalista. O mandato atribuído a Cristo e proclamado imediatamente antes do episódio da ascensão ao Céu - "Ide pelo mundo inteiro e proclamai o evangelho a toda a criatura" $(\mathrm{Mc} 16,15)$ - projeta o cristianismo como religião de toda a humanidade. A meta da sua expansão passa a ser o mundo todo, o mundo global. Nunca até então, na história das religiões, um projeto religioso tinha afirmado tão claramente a ambição de atingir o orbe no seu conjunto e de substituir liminarmente todas as outras experiências religiosas, classificadas à partida como pagãs. E este ideário tornar-se-á um poderoso motor científico, ou seja, o móbil para o conhecimento e reconhecimento do mundo.

S. Paulo fala, nas suas epístolas canónicas, da aspiração do anúncio universal da boa nova como nova criação: a palavra do Verbo iria fazer novas todas coisas. Foi de facto o apóstolo das gentes que contribuiu para desnacionalizar o embrião fundador das primeiras comunidades cristãs, vencendo o debate sobre este tema que foi crítico no primeiro Concílio de Jerusalém, contra a posição de Pedro, que encabeçava a perspetiva judaizante e fechada da mensagem de Cristo. É a teologia paulina que abre as portas do cristianismo aos não judeus, fundamentando o seu projeto universalizante. Esta teologia profética assume uma conceção do mundo como regresso da humanidade ao seu telos mítico e ideal, conceção que, em Portugal, um intérprete paradigmático como António Vieira aplica como grelha de leitura para explicar o sentido da primeira globalização moderna, tecida através do desbravamento dos caminhos dos mares por portugueses e espanhóis: "tal é a história, portugueses, que vos presento, e por isso na língua vossa. Se se há de restituir o mundo à sua primitiva inteireza e natural formosura, não se poderá concertar um corpo tão grande sem dor e sentimento dos membros que estão fora de seu lugar. Alguns gemidos se hão de ouvir entre os vossos aplausos, mas esses também fazem harmonia" (Padre António Vieira, citado em Franco \& Calafate, 2013a, p. 74). Encontramos aqui claramente a inspiração subjacente da teologia paulina nos gemidos semelhantes aos do parto materno que antecederiam a nova criação3.

\footnotetext{
${ }^{3}$ Cf. a Epístola aos Romanos, de S. Paulo: "penso, com efeito, que os sofrimentos do tempo presente não têm proporção com a glória que deverá revelar-se em nós. De facto, a criação foi submetida à vaidade - não por seu querer, mas por vontade daquele que a submeteu - na esperança de ela também ser libertada da escravidão da corrupção para entrar na liberdade da glória dos filhos de Deus. Pois sabemos que a criação inteira geme e sofre as dores de parto até ao presente. E não somente ela. Mas também nós, que temos as primícias do Espírito, gememos interiormente, suspirando pela redenção do nosso corpo" (Rm 8, 18-23).
} 
Portanto, a primeira globalização moderna é interpretada à luz de um paradigma religioso que a entende como uma nova criação, ou melhor, uma plenificação da criação divina feita através do processo de (re)conhecimento humano do conjunto das realidades criadas no horizonte de toda a Terra.

À luz deste programa globalista, os primeiros textos cristãos tinham também estabelecido o mito de que o evangelho teria sido pregado inicialmente em todo o mundo pelos apóstolos, enviados a evangelizá-lo. O mito da protopregação universal consolidou-se progressivamente: durante a Idade Média e ainda nos alvores da modernidade, acreditava-se que os apóstolos tinham repartido entre si as partes do mundo, a fim de as evangelizarem a todas.

Um tópico religioso que despertou grande interesse nos missionários jesuítas foi a crença, registada em algumas tribos ameríndias, numa figura superior, um ídolo denominado Pai-Sumé ou Zomé. Os Jesuítas associaram este nome ao do apóstolo S. Tomé, acerca do qual narrava uma lenda que teria empreendido a evangelização primitiva das Índias orientais e ocidentais; o nome e os elementos recolhidos e adaptados pelos mis-

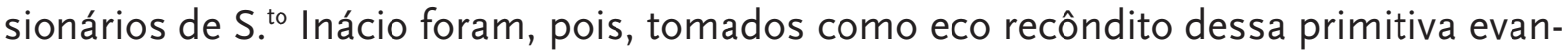
gelização. Note-se que esta interpretação não é feita ex nihilo; é realizada com base numa outra tradição antiga, que afirmava que teria sido Jesus a distribuir os apóstolos pelos quatro cantos da Terra ${ }^{4}$, tendo deste modo sido lançadas as sementes do evangelho em todo o orbe terrestre numa primeira evangelização, da qual teriam ficado vestígios residuais, que os missionários modernos deveriam saber recuperar e fazer frutificar ${ }^{5}$.

Segundo a documentação de que dispomos hoje, terá sido o P.e Manuel da Nóbrega o primeiro a divulgar aquela insólita notícia, numa carta escrita de Salvador a Martín de Azpicuelta, conhecido por Doutor Navarro, a 10 de agosto de 1549: "têm [os índios tupi-guaranis] notícia de São Tomé e de um seu companheiro; e nesta Baía estão umas pegadas numa rocha que se têm por suas, e outras em São Vicente, que é no cabo desta costa" (Nóbrega, 1955, pp. 49-50). E completa esta informação com uma explicação mais desenvolvida na "Informação das terras do Brasil aos padres e irmãos de Coimbra", desse mesmo ano:

dizem eles que Santo Tomé, a que chamam Zomé, passou por aqui. Isto Ihes ficou por dito dos seus antepassados. E que as suas pisadas estão sinaladas junto de um rio, as quais eu fui ver por mais certeza, e vi com os próprios olhos quatro pisadas muito sinaladas com os seus dedos, as quais algumas vezes cobre o rio quando enche. Dizem também que quando deixou estas pisadas ia fugindo dos índios que o queriam frechar, e chegando ali se lhe abrira o rio e passara por meio dele, sem se molhar à outra parte. E dali foi para a Índia. Assim mesmo contam que quando o queriam frechar os índios, as frechas se tornavam para eles e os matos the faziam caminho por onde passasse. Dizem também que lhes prometeu que havia de tornar

\footnotetext{
${ }^{4}$ Desta narrativa mítica já tinha feito eco a pena de Duarte Pacheco Pereira (1988).

${ }_{5}^{5}$ Sobre este assunto, ver o estudo aprofundado de Luís Filipe Thomaz (1991).
} 
outra vez a vê-los. Ele os veja do céu, e seja seu intercessor por eles a Deus, para que venham a seu conhecimento e recebam a Santa Fé como o espera. (Nóbrega, 1955, pp. 66-67)

Esta lenda estava tão arreigada nas mentes dos missionários dos séculos XVI e XVII que também encontra eco noutros autores, como é o caso do grande pregador António Vieira, que não deixa de lhe fazer referência, registando-a assim num dos seus mais belos e acutilantes sermões:

repreendeu Cristo aos Discípulos da incredulidade, e dureza de coração, com que não tinham dado crédito aos que $O$ viram ressuscitado; e sobre esta repreensão os mandou que fossem pregar por todo o mundo. A São Pedro coubelhe Roma, e Itália; a São João, a Ásia Menor; a Santiago, Espanha; a São Mateus, Etiópia; a São Simão, Mesopotâmia; a São Judas Tadeu, o Egito; aos outros, outras Províncias; e finalmente a Santo Tomé, esta parte da América, em que estamos, a que vulgar, e indignamente chamaram Brasil. Agora pergunto eu: e porque nesta repartição coube o Brasil a Santo Tomé, e não a outro Apóstolo? Ouvi a razão. Notam alguns Autores modernos que notificou Cristo aos Apóstolos a pregação da Fé pelo mundo, depois de os repreender da culpa da incredulidade, para que os trabalhos, que haviam de padecer na pregação da Fé, fossem também em satisfação, e como em penitência da mesma incredulidade, e dureza de coração, que tiveram em não quererem crer: Exprobavit incredulitatem eorum, et duritiam cordis, et dixit illis: Euntes in mundum universum. E como Santo Tomé entre todos os Apóstolos foi o mais culpado na incredulidade, por isso a Santo Tomé lhe coube na repartição do mundo a missão do Brasil. (Padre António Vieira, citado em Franco \& Cafalate, 2013b, pp. 249-250)7

Os teólogos e missionários modernos tinham estabelecido uma explicação mais ou menos consensual para a rarefação das marcas globais dessa mitificada primeira evangelização global, atribuindo-a a vicissitudes históricas e ao acentuar de uma certa compartimentação do mundo; a memória dessa primeira evangelização global ter-se-ia, pois, perdido ou chegado aos tempos coevos de forma residual. A atividade evangelizadora de S. Tomé na América e a existência do reino do Prestes João, buscado com afã pelos exploradores e missionários europeus no interior da África ou da Ásia, são exemplos que se enquadram nesse imaginário mítico do primeiro anúncio global da boa nova.

Mas o mundo que se pensava que tinha sido conhecido e percorrido globalmente como que se tornara ocluso para si próprio, fechando-se em vasos não comunicantes.

\footnotetext{
${ }^{6}$ O próprio P.e Fernão Cardim (1540-1625), outro missionário de grande nomeada, chegou a referir que os índios brasileiros arranjavam o cabelo à moda de S. Tomé, "de que tiveram alguma notícia ainda que confusa" (Cardim, 1978, p. 106).

7 Célebre pregador serviu-se desta tradição lendária para incomodar as consciências dos seus ouvintes num dos seus mais exuberantes sermões. Recorda-lhes que, se S. Tomé teve a dita sorte de evangelizar as terras de Vera Cruz, tal se deveu a um castigo decretado por Cristo, pelo facto de este seu apóstolo ter duvidado da ressurreição do Salvador; o castigo consistiu em enviá-lo a pregar a boa nova àquela mais remota gente do orbe terrestre, que tinha o coração mais duro do que o faraó do Egito.
} 
O mundo encantou-se, que o mesmo é dizer que ficou inacessível ou inapreensível no seu todo (Gauchet, 2004). O dealbar da modernidade, com as suas viagens marítimas apelidadas de descobrimento, teria sido, de acordo com este esquema hermenêutico da história, o instrumento para realizar o desencantamento do mundo.

\section{RAZÃo RELIGIOSA E PROTOGLOBALIZAÇÃo MODERNA}

Os séculos XV e XVI - ou seja, 1500 anos depois - veem, portanto, ressurgir em força a possibilidade de refazer esse sonho primeiro de globalização religiosa, de universalização do cristianismo, que fora como que interrompido e adiado na sua realidade começada.

As viagens marítimas promovidas a partir das monarquias ibéricas de Portugal e Espanha são, pois, legitimadas ao mais alto nível pelas lideranças políticas e religiosas à luz desse ideário religioso primigénio. Com efeito, tanto na parenética dos oradores sacros do movimento expansionista ibérico, como nas determinações legislativas régias que estabelecem as razões deste investimento, a razão religiosa surge à cabeça, como a mais importante para justificar o risco das viagens de conhecimento e expansão (Baptista, Franco \& Cieszyńska, 2014, p. 103). Portugal conquista Ceuta e, a partir daí, todo o Norte de África sob domínio mouro para recuperar velhos territórios cristãos para a Igreja, e explica as viagens marítimas com o intento de descobrir novas gentes e novos povos a que levar a luz do evangelho, ou para reencontrar, no interior de África ou da Ásia, comunidades cristãs perdidas, sobreviventes da primeira evangelização, com as quais se teria perdido o contacto.

À luz deste móbil, o cristianismo projeta-se por todos os continentes e torna-se um fator decisivo para a promoção da primeira globalização efetiva. Os agentes do mundo compartimentado em povos, nações, culturas e religiões, até então isolados, conectam-se entre si e passam a interagir, a relacionar-se e a sofrer processos de intercâmbio e transferências culturais, de aculturações, interfecundações, etc..

Tiveram papel relevante neste processo as ordens religiosas com vocação missionária. Recorde-se que as ordens religiosas foram uma criação protomedieval, sofrendo, ao longo de cerca de mil anos, adaptações e metamorfoses, com especial enfoque na reforma mendicante do século XII e na criação dos Jesuítas, no século XVI. Sendo uma criação medieval, o carácter multinacional que o seu modelo de organização veio a adquirir fez delas as estruturas mais bem preparadas para se adaptarem ao mundo que haveria de emergir na modernidade: um mundo marcado pela mobilidade planetária (Franco, 2011). Com efeito, Dominicanos, Franciscanos e Jesuítas, só para referir alguns, vão projetar missionários em todos os continentes através da rede imperial portuguesa e espanhola, e usando as condições e os privilégios concedidos pelo papa aos monarcas destes reinos ibéricos, que assim fundam os chamados padroado português e espanhol, estabelecidos para patrocinar o projeto de globalização do cristianismo (Franco \& Abreu, 2014).

Estas ordens, posicionando-se para o grande objetivo universal por via da atualização da utopia medieval do estabelecimento de um reino cristão global com a chegada do imperador dos últimos dias, vão criar uma série de instrumentos de alcance geral 
para servir este ideário religioso, nomeadamente adaptando a sua estrutura organizativa para este efeito, e criando um sistema de comunicação global, para o qual exploram as vantagens da descoberta da imprensa e o nascimento da cultura de massas, através do poder multiplicador da escrita mimeografada pelo prelo gutenberguiano (Almeida, 2017; De Koninck, 2003; Martins, 2011). Os Jesuítas, ao lado das outras ordens missionárias, tiveram um papel relevante neste processo a partir da península Ibérica, usando os instrumentos dos já referidos padroados português e espanhol para projetar instituições a nível intercontinental (Alden, 1996).

\section{PRIMEIRAS REDES E INSTITUIÇões GLOBAIS}

As missões das ordens religiosas missionárias que ganham presença intercontinental tornam-se polos de difusão da língua portuguesa, que é a primeira língua europeia, seguida da espanhola, a adquirir dimensão global. Através de uma correspondência intensiva, de relatórios e de tratados religiosos, culturais e científicos, constitui-se nesta época uma primeira base de dados universal, operando-se, através do conhecimento, o domínio de toda a realidade criada, acentuando a ideia primigénia dos seres humanos como cuidadores, organizadores ou feitores de um senhorio que pertencia ao Deus global.

As missões cristãs financiadas pelas potências europeias constroem um cristianismo global, tornando-se instrumentos de civilização, mas também de trocas culturais, linguísticas, etc. Os missionários, que eram dos agentes intelectualmente mais qualificados deste período, contribuem para reunir informação sobre o mundo que se estava a descobrir globalmente. Através da rede de missões, e ao lado das instituições coloniais que se vão criando nos impérios europeus - quais observatórios do mundo que se dava a conhecer ao mesmo mundo -, constituíram o primeiro repositório do saber global; com efeito, Jesuítas, Franciscanos, Dominicanos, Agostinhos e Carmelitas, entre outros, movidos pelo ideário de anúncio do evangelho, iam registando e estudando o que observavam, aprendiam, gramaticalizavam e dicionarizavam muitas línguas até então desconhecidas, elaboravam histórias de povos e de países que não tinham a sua história feita ao modo ocidental, etc. Deste modo, a motivação religiosa que levou milhares e milhares de missionários a todos os cantos da Terra favoreceu a primeira grande operação global de conhecimento do mundo.

Do mesmo modo, cumpre destacar, no caso emblemático das iniciativas globais da Companhia de Jesus (Lowney, 2006), a criação da primeira rede global de ensino, um sistema de colégios regidos pelo mesmo regimento em todos os continentes onde se implantaram e reimplantaram (até hoje), a famosa ratio studiorum aprovada em 1599, que vigorou desde o Japão até ao Peru. Para atender a este desafio global de educação, foram criados, também neste contexto e para servir esta rede - sendo Portugal uma plataforma importante para o efeito -, os primeiros manuais globais de ensino, com destaque para a Gramática Latina do Jesuíta Manuel Álvares, reitor do Colégio das Artes de Coimbra, e os famosos manuais de filosofia, produzidos também em Coimbra, que 
formavam o chamado Cursus Conimbricencis, e que serviram de base ao ensino médio e pré-universitário em toda a Europa e noutros continentes, até à China (Banchoff \& Casanova, 2016). Por este curso se formaram grandes luminares proto-iluministas e iluministas europeus, como Descartes, Leibniz e Voltaire.

As novas e emergentes instituições, acompanhadas da construção de edifícios globais mimetizados com adaptações, tiveram influência na arquitetura a na arte religiosa, uma influência que favoreceu interconexões e interfecundações que deixaram marcas até hoje. No âmbito deste esforço de cristianização global, em que o nome de Cristo foi, pouco a pouco, pregado em todos os continentes, temos, entre outros, um caso paradigmático de interfecundação no plano linguístico verificado na Ásia: o atual Vietnam passou a usar o alfabeto latino na escrita da sua língua anamita devido à influência dos missionários jesuítas que ali trabalhavam, idos pela via do padroado português do Oriente, que funcionava como rampa de projeção destes padres e de outras ordens que começaram a espalhar novos campos de missão até ao Extremo Oriente.

Deste modo, Portugal foi, ao lado da vizinha Espanha e seguido depois pelas emergentes potências europeias, através dos seus agentes religiosos e também políticos, pioneiro e protagonista de uma atitude moderna de criação no campo das experiências e dos saberes, enriquecidos pelos referidos contactos, confrontos e intercâmbios. Boaventura de Sousa Santos dá em parte conta de tal dinamismo de continuidade no seu livro sobre Portugal:

o momento inicial da expansão foi um momento extremamente criativo. Constitui um campo de possibilidades caóticas, tão vulneráveis às fulgurações quanto ao aventureirismo próprio e alheio, tão excitantes quanto medíocres, tão justificativas de "Os Lusíadas" como de "O Soldado Prático". Essa criatividade permitiu a Portugal ter sido um dos protagonistas da primeira modernidade europeia, a modernidade ibérica (...). É a modernidade de Pedro Fonseca, o Aristóteles português, e de Suarez, a modernidade dos Conimbricenses, como foram ao tempo conhecidos. A obra de Pedro da Fonseca teve 36 edições e foi lida por Descartes e Leibniz. Ou seja, o que veio a ser designado por modernidade europeia, de Descartes a Kant, foi de facto uma segunda modernidade, a da Europa Central, que se alimentou da modernidade ibérica, uma modernidade que, por ter sido protagonizada por países que entraram rapidamente em decadência, não foi reconhecida como tal nos séculos seguintes. Esta modernidade que Portugal, de algum modo, perdeu foi um longo período de inserção dependente que gerou o que designei acima por problema do passado. (Santos, 2011, p. 78)

\section{O PENSAMENTO UTÓPICO COMO RESPOSTA ÀS CRISES DA GLOBALIZAÇÃO}

Neste período, gerou-se entre a velha cristandade europeia o sentimento eufórico de que a história do cristianismo e da Igreja cristã, até então circunscrita a uma pequena 
porção do planeta, poderia ser globalizada, cumprindo o projeto de universalização do cristianismo, mas também lembrando as profecias premonitórias de que a realização desta meta preludiaria o fim do mundo, ou então o dealbar, não sem acontecimentos tormentosos, de uma idade beatífica de paz e santidade, a última idade da história, o Grande Sábado 8 .

No entanto, rapidamente se percebeu que esta expectativa de mudança do curso e da natureza da história humana não se realizava; pelo contrário, prosseguiu e acentuou-se a generalização dos conflitos tradicionais, somados às novas fraturas que despoletaram na história da cristandade europeia ${ }^{9}$. A Europa conheceu divisões religiosas, confessionalizando o cristianismo, e as guerras fratricidas que a ensanguentam tornaram-se também, consequentemente, globais (Eire, 2016).

À desilusão resultante da expectativa gorada da aceleração da história em direção a uma palingenesia final respondeu o pensamento utópico. Através da análise da evolução do processo e dos modelos de construção das utopias na modernidade, podemos compreender o progresso da perceção do mundo que passava a ser visto como global, e as respostas dadas às preocupações que daí advêm, também de alcance global ${ }^{10}$. Recuperamos aqui a importante nota de José Mattoso sobre a afirmação da consciência da possibilidade de perfetibilidade humana na modernidade:

começo por fazer notar que a crença no futuro e a noção de que a Humanidade caminha para um mundo melhor exprimem uma das ideias típicas da civilização ocidental na época moderna. Não se pensava assim antes do tempo dos Descobrimentos, nem nos outros continentes. Simplificando muito, pode dizer-se que quando os europeus começaram a conhecer as outras civilizações e se deram conta da sua superioridade técnica no

\footnotetext{
${ }^{8}$ Recorde-se que, na perspetiva cristã, a etapa final da história consistiria na evangelização e conversão de todos os povos; foi por isso que, na modernidade, emergiu a convicção de que se tinha inaugurado uma etapa decisiva nessa progressão. O P.e António Vieira é em Portugal, à semelhança de outros autores europeus, um excelente intérprete desta consciência emergente. Convencido de que a evangelização global em curso, que as viagens de descobrimento tinham facilitado, corresponderia a uma determinação especial de Deus e a uma vocação especial dos descobridores, não hesita em comparar os descobrimentos portugueses a uma nova epifania: “a primeira vocação da Gentilidade foi 'nos dias de Herodes': In diebus Herodis Regis; a segunda quase em nossos dias. A primeira foi 'quando Cristo nasceu': cum natus esse Jesus, a segunda quando já se contavam Mil e quinhentos anos do nascimento de Cristo. A primeira foi 'por meio dos Reis do Oriente': Ecce Magi ab Oriente venerunt; a segunda por meio dos Reis do Ocidente, e dos mais Ocidentais de todos, que são os de Portugal" (Padre António Vieira, citado em Franco \& Cafalate, 2013c, p. 354). Esta ideia foi desenvolvida no "Sermão da epifania", pregado na Capela Real no ano de 1662. Esta teologia cristã da história segue claramente uma determinação filosófica da história, onde a constituição do Império português cristão constitui um avanço decisivo, que, como é evidente, difere qualitativamente da história anterior. Assim, a história da salvação adquire, no século de Quinhentos, uma amplitude universal: de uma universalidade em potência passa para uma universalidade quase completa (Valente, 1980).

${ }_{9}$ Atente-se que, em termos gerais, "no momento em que se afirmaram as nações europeias, reforçou-se a unidade da civilização ocidental; dois fenómenos aparentemente contraditórios e, no entanto, solidários, cuja dialética é uma das maiores características do período que estamos a estudar. A descoberta e exploração dos mundos exóticos viria, ao mesmo tempo, avivar as tensões entre os europeus e precisar ainda mais a comunidade dos seus destinos" (Delumeau, 1994, p. 48; Nisbert, 1980).

${ }^{10}$ A utopia milenarista, muito desenvolvida e difundida, sob diversas formas e manifestações, na Idade Média, a partir, principalmente, da matriz patente no cap. 20 do Apocalipse de João, conhece uma concretização muito especial, destacando-se por uma arquitetura teológica bastante trabalhada e por uma visão global da história que pretende ser, além do seu carácter prospetivo, uma leitura crítica das instituições da Igreja do presente (Delumeau, 1997).
} 
domínio militar, pensaram poder dominar todo o universo, e caminhar assim para uma sociedade que abrangesse a Humanidade inteira. Esta ideia durou séculos a germinar e a transformar-se em princípio de ação. Em certas correntes revestiu formas racionais e morais, noutras predominaram aspetos económicos e técnicos, noutras ainda manifestou-se como crença num progresso social e político. (Mattoso, 2012, pp. 63-64)"

É neste contexto que se desenham importantes correntes de pensamento utópico, para dar resposta aos desafios que as sociedades humanas enfrentavam no quadro da nova mundividência global e dos dramas e expectativas dela decorrentes.

Distinguem-se duas correntes claras de solução utópica para o destino da humanidade neste processo moderno de conhecimento, reconhecimento e preocupação com a deriva da humanidade num mundo que se globalizava: uma corrente exclusivista e outra inclusivista.

A exclusivista é antiglobalista e parte de uma perceção muito pessimista do estado geral da humanidade e da possibilidade de ela ser regenerada no seu todo. Produções utópicas paradigmáticas desta corrente são a ilha da Utopia de Tomás Moro e a Cidade do Sol de Tommasio de Campanella. A possibilidade da construção de uma sociedade feliz implica, nesta perspetiva, uma nova oclusão, ou seja, passa por criar um espaço isolado, projetado num lugar restrito, onde uma porção pequena da humanidade possa viver com regras e valores bem definidos, e distintos dos da grande massa humana. Estas utopias, elitistas e antiglobais, nasceram no dealbar da modernidade, no seio de sociedades ou países como Inglaterra, que se definia a si própria como país-ilha, isolada do continente europeu, e Itália, dividida num quebra-cabeças de cidades-Estado'2.

As utopias inclusivistas, por seu lado, começam a elaborar-se mais intensamente na viragem para o século XVII, numa altura em que o conhecimento do planeta se encontra mais consolidado e em que a presença imperial das potências europeias está projetada intercontinentalmente. Esta corrente de pensamento é paradigmática do ideário de afirmação da esperança num futuro melhor para a humanidade no seu todo (Dias, 1960).

Uma delas, e bem emblemática, é a utopia do Quinto Império idealizada em Portugal, tendo como um dos seus mais geniais representantes António Vieira. Registaram-se elaborações homólogas em Espanha, e a ideologia quinto-imperialista encontrará uma genealogia metamórfica em vários países e tempos até ao séc. Xx. O pensamento utópico quinto-imperialista, especialmente no caso de Vieira e das suas obras mais representativas (História do Futuro e Clavis Prophetarum), toma o mundo inteiro como palco sem fronteiras da possibilidade de a humanidade viver feliz no quadro de uma unidade cristã essencial, mas admitindo diversidade de expressões cultuais e de tradições cívicas. A

\footnotetext{
"De facto, o recurso à especulação utópica constitui, segundo o P.e Manuel Antunes, "o fruto sazonado" principalmente das épocas de crise e dos tempos de crítica. "A utopia coaduna-se com a emergência da transformação individual e coletiva que o homem experimenta, com a exigência de esperar inscrita na sua natureza, com a capacidade de extrapolar a realidade e de recriar mundos novos pela ação conjunta da imaginação e da razão, no impulso de se projetar-se na dimensão do possível. Deste modo, a utopia tem a ver com a ideologia, com a escatologia, com a mitologia, com a profecia e com a prospetiva" (Padre Manuel Antunes, citado em Franco, 2007, p. 403).
}

12 Sobre o tema da utopia ver Ricoeur (1991). 
utopia de Vieira e as soluções por ele apresentadas para um mundo fraturado por guerras entre potências europeias, decorrentes, como se referiu, de ambições territoriais e da confessionalização do cristianismo em Igrejas separadas, são de inspiração religiosa, mas visam um progresso da humanidade em ordem a uma vida de paz, fraternidade e bem-estar generalizado (Franco \& Mourão, 2005). De facto, como bem analisou o estudioso francês Raimund Cantel (1963), tais propostas foram precursoras de projetos laicos para a paz no mundo concebidos nos sécs. XIX e XX, entre os quais o ideário que esteve por trás da construção de uma autoridade mundial para regular o relacionamento entre os povos e estabelecer a concórdia entre as nações.

O pensamento utópico moderno, de fundo religioso cristão, é um bom indicador da perceção de um mundo que se globalizava e da consciência emergente das virtualidades, mas também dos graves problemas que estavam a advir do movimento globalizador. Este movimento, que se tornou imparável até hoje, tanto abriu as portas ao relacionamento entre os povos, que passaram a olhar-se de frente, fazendo desabar mitos e visões estereotipadas do mundo, quanto - não tenhamos ilusões - acicatou velhos e novos estereótipos antagonizadores.

De qualquer modo, este tempo matricial da globalização revolucionou não só as velhas mundividências, mas a própria ideia de ciência e as possibilidades do conhecimento para o progresso humano. Hoje é claro que os "descobrimentos" contribuíram para a produção de uma ciência e uma cultura novas, que mudaram a visão do mundo planetário e o próprio mundo europeu, quer nas paisagens das relações exteriores, quer nas paisagens interiores do pensamento humano. Como bem demonstra em volumosa obra recente David Wootton (2017, pp. 75, 79-80),

a ideia de descobrimento é contemporânea dos planos de Colombo (...) porque é o mesmo descobrimento que transformou o nosso mundo. (...) Antes do descobrimento supunha-se que a história se repetia e que a tradição proporcionava um guia razoável para o futuro; e acreditava-se que as maiores conquistas da civilização não se observavam no presente, mas no passado, na antiga Grécia e na Roma clássica. É fácil dizer que o nosso mundo atual foi feito pela ciência e pela tecnologia, mas o progresso científico e tecnológico depende de um pressuposto prévio, o pressuposto de que há descobrimentos a fazer. (...) Foi esta suposição de que há novos descobrimentos a realizar que operou a transformação do mundo, porque tornou possível a ciência e as tecnologias modernas.

Opera-se então uma transformação da visão do mundo que se reflete na transformação linguística da ideia de ciência e da possibilidade de a história se tornar de facto um movimento de progresso com horizonte de perfetibilidade crescente.

Outra das consequências mais importantes deste processo, na sequência do qual a Europa se torna um continente imperial com domínios globais, foi a afirmação de uma civilização, a dita ocidental, que engrandeceu o seu sistema de valores, querendo validá-los como universais e passando a querer impô-los a toda a humanidade. Ainda hoje 
não ultrapassámos, com efeito, o paradigma ético que continua a gerar debate sobre a existência de valores universais, sendo esses os que são identificados com a civilização ocidental. Contudo, deixou de ser possível impor valores universais a partir de uma matriz civilizacional de referência, sendo necessário reconhecer, no quadro da comunidade internacional, a existência de um conjunto mínimo de valores comuns a todas as civilizações, culturas, povos e religiões, que permitem a assunção do homo fraternus, inter pares, um ideal de homem capaz de viver em fraterna concórdia com os seus iguais, mas também fraterno para com a natureza, de modo a assegurar, na sua qualidade de cuidador, a maior harmonia ecológica possível.

\section{CONCLUSÕES PROVISÓRIAS}

Quando tentamos compreender dinamismos que suscitaram interconexões e interações globais, não podemos deixar de ter bem presente que, neste domínio, o trabalho do historiador não é, como escreve Sebastian Conrad (2017, p. 16), "escrever uma história total do nosso planeta", mesmo explorando um determinado movimento da história, seja ele religioso, cultural ou político; apenas podemos almejar ter "em mente as conexões globais e as condições estruturais", para podemos tentar compreender algumas dominantes de longuíssima duração e as suas mudanças em momentos charneira, que desabrocham depois de uma grande maturação. De facto, como lembra o estudioso citado, a "história global, portanto, não é sinónimo de 'macro-história'. Muitas vezes na história global os problemas mais interessantes surgem no ponto de interseção entre os processos globais e as suas manifestações locais".

Considerando esta esteira teórica, e tendo em conta que nos situamos no domínio da história religiosa, do imaginário e das mentalidades, podemos problematizar o fenómeno da protoglobalização despoletada na época moderna como tendo na sua raiz um móbil religioso, como religiosas são a sua legitimação e explicação. E foi ainda do meio religioso que vieram os primeiros instrumentos e soluções globais para atender aos desafios trazidos pelo processo de conhecimento do mundo, em que os povos abriam as portas para serem vistos e conhecidos e receberem, em paz ou em guerra, as interinfluências dessa escancarada abertura.

Hoje, em pleno séc. xxi, esquecemos, em grande medida, o tempo seminal do atribulado início desta globalização que habitamos de forma plena, mas não menos atribuladamente. Muitos dos instrumentos criados, com inspiração e motivação religiosa, nos séculos XVI e XVII, para responder a um mundo global que então se abria à Europa, são hoje reproduzidos de modos e por meios variados, de que as multinacionais económicas e financeiras são a melhor expressão, embora sem esse referente religioso. De facto, o processo moderno de secularização acabou por cortar o fio de ligação com o religioso, assumindo um cunho laico e civil.

Todavia, não podemos esquecer que esse tempo da protoglobalização foi um tempo por excelência para rever e refazer os velhos mitos e gizar novas soluções, em vista da construção de futuros mais perfeitos para a humanidade, que então se apresentava 
de corpo inteiro pelo conhecimento escrito e pelos contactos dos viajantes globais. $O$ religioso teve, neste momento auroral da modernidade globalizada, um papel decisivo e modelador no processo humano nunca acabado de construir e desconstruir narrativas e utopias, que são os mapas de sentido da humanidade; e são esses mapas que hoje continuamos a fazer e a refazer incansavelmente. Vale a pena avocar esta passagem bem lúcida de Ronald Wright (2004, p. 19):

a nossa civilização, que inclui a maior parte das suas predecessoras, é um grande navio a todo o vapor em direção ao futuro. Viaja mais depressa, mais longe e com mais carga do que qualquer uma das anteriores. Podemos não conseguir prever todos os perigos e escolhos, mas lendo o ângulo e a direção da bússola, compreendendo o seu desígnio, o seu historial de segurança e os conhecimentos da tripulação, podemos, penso eu, traçar uma rota racional entre os estreitos e os icebergs que nos surgem pela frente. (...) Temos tendência a considerar a nossa época como excecional e realmente é sob muitos aspetos. Mas a falta de uma visão global vivida no presente, o modo como os nossos olhos seguem a bola e não o jogo, é muito perigosa.

A mesma inquietude em relação ao futuro da humanidade permanece e perturba o coração dos homens. Hoje - diferentemente do que eram as expectativas dominantes de há 500 anos, situadas mais num horizonte espiritual e explicadas teologicamente - coloca-se o problema da sobrevivência da própria humanidade, devido ao desgaste que ela tem produzido na natureza que tinha a vocação de cuidar. Mais do que nunca se pede, se exige e se pensa a urgência de uma reforma da própria humanidade e da sua consciência na relação com o mundo criado, ou gerado, ou formado (consoante as óticas religiosas e científicas em que nos situamos). A proposta de uma ética global defendida por Hans Kung (2007), procurando pontos de entendimento e valores comuns a partir dos diferentes patrimónios éticos gerados pelas diversas religiões do mundo, tem cada vez mais pertinência no contexto atual. Por seu lado, essa necessária reforma global passará, em grande medida, pelo trabalho de fundo advogado por Edgar Morin (2015, pp. 98-99):

o único presente que nos pode preparar para o futuro será a realização de uma reforma do conhecimento e do pensamento, a que chamo complexo, que não nos dará a infalibilidade, mas que nos permitirá fazer menos erros e ter menos ilusões e menos cegueiras: um pensamento global.

\section{REFERÊNCIAS BIBLIOGRÁFICAS}

Alden, D. (1996). The Making of An Enterprise. The Society of Jesus in Portugal, Its Empire, and Beyond (15401750). Stanford: Stanford University.

Almeida, O. T. de (2017). A Obsessão da portugalidade. Lisboa: Quetzal. 
Banchoff, T. \& Casanova, J. (Eds.) (2016). The Jesuits and Globalization: Historical Legacies and Contemporary Challenges. Washington, DC: Georgetown University Press.

Baptista, M. M.; Franco, J. E. \& Cieszyńska, B. (Eds.) (2014). Europa das Nacionalidades: Imaginários, Identidades e Metamorfoses Políticas. Coimbra: Grácio Editor.

Barreto, L. F. (1996). A Ciência e os Descobrimentos. Lisboa: JNICT.

Cantel, R. (1963). Prophétisme et Messianisme dans l'Oeuvre de Antonio Vieira. Paris: Ed. Hispano-Americanas.

Cardim, F. (1978). Tratado da Terra e Gente do Brasil. São Paulo: Universidade de São Paulo.

Conrad, S. (2017). Historia Global: Una Nueva Visión para al Mundo Actual. Barcelona: Crítica.

De Koninck, T. (2003). A Nova Ignorância e o Problema da Cultura. Lisboa: Edições 70.

Delumeau, J. (1994). A Civilização do Renascimento. Lisboa: Editorial Estampa.

Delumeau, J. (1997). Mil Anos de Felicidade: Uma História do Paraíso. Lisboa: Terramar.

Dias, J. S. S. (1960). Correntes de Sentimento Religioso em Portugal (Sécs. XVI a XVIII). Coimbra: Imprensa da Universidade de Coimbra.

Dubois, C.-G. (1972). Celtes et Gaulois au XVI Siècle. Le Développement Littéraire d'Un Mythe Nationaliste, avec l'Édition Critique d'Un Traité Inédit de Guillaume Postel de ce Qui Est Premier pour Reformer le Monde. Paris: Vrin.

Eire, C. M. N. (2016). Reformations. The Early Modern World (1450-1650). Londres: Yale University Press.

Epístola aos Romanos, S. Paulo, (Rm 8, 18-23).

Eusébio de Cesareia (2017). História Eclesiástica. São Paulo: Paulus.

Franco, J. E (Ed.) (2007). Obra Completa Padre Manuel Antunes. Lisboa: Fundação Calouste Gulbenkian.

Franco, J. E. \& Abreu, L. M. (Eds.) (2014). Para a História das Ordens e Congregações Religiosas em Portugal, na Europa e no Mundo. Lisboa: Paulinas.

Franco, J. E. \& Calafate, P. (Eds.) (2013a). História do Futuro. Padre António Vieira Obra Completa, Tomo 3, Vol. 1. Lisboa: Círculo de Leitores.

Franco, J. E. \& Calafate, P. (Eds.) (2013b). Sermões da Páscoa e do Pentecostes. Padre António Vieira Obra Completa, Tomo 2, Vol. 5. Lisboa: Círculo de Leitores.

Franco, J. E. \& Calafate, P. (Eds.) (2013c). Sermões do Advento, do Natal e da Epifania. Padre António Vieira Obra Completa, Tomo 2, Vol. 1. Lisboa: Círculo de Leitores.

Franco, J. E. \& Mourão, J. A. (2005). Influência de Joaquim de Flora em Portugal e na Europa. Escritos de Natália Correia sobre a Utopia da Idade Feminina do Espírito Santo. Lisboa: Roma Editora.

Franco, J. E. (2000). O Mito de Portugal. A Primeira História de Portugal e a Sua Função Política. Lisboa: Fundação Maria Manuela e Vasco Albuquerque d'Orey/Roma Editora.

Franco, J. E. (Ed.) (2011). O Esplendor da Austeridade: 1000 Anos de Empreendedorismo das Ordens e Congregações em Portugal - Arte, Cultura e Solidariedade. Lisboa: INCM.

Gauchet, M. (2004). Un Monde Désanchanté. Paris: Éditions de l'Atlier/Éditions Ouvrières. 
Kung, H. (2007). Projeto para Uma Ética Mundial. Lisboa: Instituto Piaget.

Kung, H. (2007). Religiões do Mundo: Em busca de Pontos em comum. Lisboa, Multinova.

Lowney, C. (2006). Liderança Heroica: As Melhores Práticas de Uma Companhia com 450 Anos Que Mudou o Mundo. Lisboa: Verbo.

Martins, M. L. (2011). Crise no Castelo da Cultura: das Estrelas para o Ecrãs. Coimbra: Grácio Editor.

Mattoso, J. (2012). Levantar o Céu: Os Labirintos da Sabedoria. Lisboa: Temas e Debates/Círculo de Leitores.

Medina, J. (1995). O sebastianismo. Exame crítico dum mito português. In J. Medina (Ed.), História de Portugal (pp. 270-271). Amadora, Clube Internacional do Livro.

Morin, E. (2015). Penser Global. Paris: Éditions Robert Lafont/Éditions de la Maison des Sciences de l'Homme.

Nisbert, R. (1980). History of the Idea of Progress. London: Heinemann Education Books.

Nóbrega, M. da (1955). Cartas do Brasil e mais Escritos. Coimbra: Acta Universitatis Conimbrigensis.

Pereira, D. P. (1988). Esmeraldo de Situ Orbis. Lisboa: Academia Portuguesa da História.

Ramada Curto, D. (2016). Estudos sobre a Globalização. Lisboa: Edições 70.

Ricoeur, P. (1986). Du Texte à l'Action. Essais d'Hermeneutique. Paris: Seuil.

Ricoeur, P. (1991). Ideologia e Utopia. Lisboa: Edições 70.

Santo Agostinho (1991-1995). A Cidade de Deus, 3 Vols.. Lisboa: Fundação Calouste Gulbenkian.

Santos, B. S. (2011). Portugal: Ensaio contra a Autoflagelação. Lisboa: Almedina.

Serrão, J. V. (1969). História e Conhecimento Histórico. Lisboa: Editorial Verbo.

Thomaz, L. F. (1991). A lenda de São Tomé apóstolo e a expansão portuguesa. Lusitania Sacra, III, 350-418.

Valente, V. P. (1980). Estudos sobre a Crise Nacional. Lisboa: INCM.

Vaz, A. (2007). No princípio da Bíblia está o mito: A espiritualidade dos mitos da criação. Didaskalia, 37, 45-73.

Wootton, D. (2017). La Invención de la Ciencia: Una Nueva Historia de la Revolución Científica. Barcelona: Editorial Planteta.

Wright, R. (2004). Breve História do Progresso. Lisboa: Dom Quixote.

Wright, R. (2011). A Evolução de Deus. Lisboa: Guerra e Paz.

\section{NotA BIOGRÁFICA}

José Eduardo Franco é professor Catedrático da Universidade Aberta e titular da $\mathrm{CIDH}$ - Cátedra FCT/Infante Dom Henrique para os Estudos Insulares Atlânticos e a Globalização (Universidade Aberta/CLEPUL - Faculdade de Letras da Universidade de 
Lisboa). É membro correspondente da Academia Portuguesa da História e Vice-Presidente da Sociedade Internacional de Estudos Jesuítas (SIEJ) com sede em Paris.

E-mail: eduardofranco.cidh@gmail.com; eduardo.franco@uab.pt

Endereço: CIDH - Cátedra Infante Dom Henrique para os Estudos Insulares Atlânticos e a Globalização

Universidade Aberta/CLEPUL - Faculdade de Letras da Universidade de Lisboa | PALÁCIO CEIA, Rua da Escola Politécnica, 147, 1269-001 Lisboa

Submetido: 02/09/2017

Aceite: $25 / 10 / 2017$ 